\title{
The Role of Black Seed and Honey in Relieving the Degree of Symptoms Associated of Breast Cancer
}

\author{
Susan Abdel Rahman Salah Abo shal ${ }^{1}$
}

\begin{abstract}
This study aimed to determine the effect of black seed and honey on the status of women with breast cancer. This study was conducted at the Department of Oncology in AlNoor Specialist Hospital and King Abdullah Medical City, Holy Makkah. The sample consisted of fifty-four patients, aged more than 18 to 70 years, and was divided into four groups. All of these groups continued the treatment of chemotherapy and the first group (14 patients) was considered as the control group: the second group (11 patients) was given a daily intake of black seed $(0.2 \mathrm{~g} / \mathrm{kg}$ body weight); the third group (14 patients) was given a daily intake of honey (60 grams); while the fourth group (15 patients) was given both the black seed and honey similar to the second and third intakes for a period of 5 days a week. Also, intakes of black seed, honey, as well as black seed and honey together continued for two weeks after the end of chemotherapy.

The results showed that the degree of pain sensation during chemotherapy was decreased with the intake of either black seed or honey. After two weeks at the end of chemotherapy and dietary treatment, nausea disappeared among $51.85 \%$ of all women. During chemotherapy, the percentage of $50 \%$ of women experienced vomiting especially between the intakes of honey and the combined black seed and honey groups. Symptoms of diarrhea disappeared after treatment and also after two weeks of treatment, especially among the honey, and a combined black seed and honey groups. The symptom of appetite loss after treatment was decreased and the perception of slight loss of appetite was $88.89 \%$ among women. Half of the women had moderate symptoms of fatigue. During sessions of chemotherapy and with intake of black seed and honey and both combined there was a symptom of mild dizziness or completely disappeared in $79.63,20.37 \%$, respectively. Symptoms of depression disappeared during treatment and also after two weeks of treatment in the three experimental groups. There was a significant degree of anxiety during chemotherapy treatment and also after two weeks in $18.52 \%$ of the sample, especially the groups of black seed, or bee honey, or both of them.
\end{abstract}

The study concluded the importance of the use of complementary and alternative treatment by using natural foods especially black seed and honey for the prevention and protection from cancer or an alleviation of symptoms associated with various cancer treatments.

\section{INTRODUCTION}

Cancer is a group of diseases (more than 100 diseases) similar in some characteristics to each other. It has been called Cancer due to the distended blood vessels around the tumor-like clusters of crab and these diseases are caused by cells getting out of control (Debasis and Preuss 2005). Cancer is one of the main problems of public health in the world; it causes the deaths of 7.1 million persons per year in various parts of the world. And it has been predicted that by 2020 there will be 15 million people newly infected with cancer each year (WHO, 2003).

In 2007, the percentage of breast cancer in Saudi Arabia between Saudi men and women were 0.5, 26.6\%, respectively compared to the other types of cancer; and the number of Saudi deaths in the same year as a result of cancer tumors generally was 1688 cases (935 males, 753 females) at the rate $6.2 \%$ of the total number of deaths in the Kingdom (Ministry of Health, 2007). This is related to the rise in the prevalence of many factors in the Kingdom of Saudi Arabia such as increased life expectancy, following the western style of living which encourages reducing the number of pregnancies, delayed childbearing, as well as the lack of physical activity and dietary habits (Ibrahim et al., 2008).

In addition drug therapy causes severe side effects such as nausea and vomiting, reaching between (12-36) hours after treatment, lesions occur in the mucous membranes lining the mouth, decreased white blood cells which reduces patient's resistance to bacterial infection, as well as a decrease in blood platelets which leads to the occurrence of hemorrhage. Also, there are common effects of chemical drugs including fatigue, weakness and pain throughout the body, weight gain and night sweats, dizziness and a change in the sense of smell and taste, headache, diarrhea or constipation and tingling in the fingers and loss of nerve strength (Mufti, 2007; Cancer Compass.2008).

A study by Alharbi (2008) which included 30 women with breast cancer, age ranged between 25 to 55 years in the Armed Forces Hospital in Riyadh showed a rate of $43.33 \%$ of anemic patients (hemoglobin less than 12 grams).

As pointed out by Edris (2009) black seed is the one famous specie well known for its medicinal properties and lack of toxicity. And the seed contains oil products by $30.0 \%-38.0 \%$ in weight, and the composition of this oil is from 97.5 to $99.9 \%$ fixed oil and about 0.1 to $2.5 \%$ volatile oils (essential). The study indicated to the great effectiveness of primary oil when injected directly into

${ }^{1}$ Faculty of Applied Medical Science, Umm Al-Qura University

Received August 12, 2012, Accepted August 28,, 2012 
the tumor in reducing tumor size, inhibition of proliferation of the tumor as well as the delay of death in mice with tumors. This effectiveness was attributed to the components of essential oil thymoquinone (TQ), which represents the main component of primary oil where most of its source comes from black seed. This phenomenon might be due to its effect on inhibition of cancer cells growth as well as its ability to stimulate programmed cell death.

The purpose of the study of Mohamad, et al., (2011) was to evaluate the effectiveness of black seed capsules, rose cedar and vitamin $\mathrm{E}$ plant on women with breast cancer. The experiment was conducted on 168 breast cancer patients that had been divided into four subgroups, each group composed of a total of 42 patients. The first group of them did not receive any treatment except the prescribed standard treatments, while the rest of the groups, in addition to the standard treatment, were treated with either black seed capsules (grams / 8 hours) or rose cedar (1.4 g / 12 hours) or vitamin E (100 mg / 12 hours) for a period of 6 months. The results showed black seed as highly effective, as it brought about an evident improvement in the levels of all biochemical measurements that had been assessed and also the general health situation in breast cancer patients more than rose cedar or vitamin $\mathrm{E}$ capsules, which were being treated chemically and radiologically. The study concluded that the use of black seed treatment is complementary with standard chemotherapy, radiation and hormone therapy for patients with breast cancer and may be useful in reducing the recurrence of the disease and improve patient survival rates. Therefore, this study aimed to identify the effect of black seed and honey as to relieving the degree of associated symptoms of those infected with breast cancer.

\section{MATERIALS AND METHODS}

This study was conducted during the academic year 1430-1431 H, corresponding to the year $2009-2010$ A.D. Research sample consisted of fifty-four patients and upon evaluation by the Department of Oncology the infected women were divided randomly into four groups; all groups continued treatment of chemotherapy and the first group (14 patients) was considered as a control group, the second group (11 patients) was given 0.2 grams of black seed/ $\mathrm{kg}$ body weight to be divided into three volumes taken after three main meals during the day, and the third group (14 patients) was given 20 grams of Cedar honey before eating at every meal of the three main meals taking 60 grams of honey during the day. While the fourth group (15 patients) was provided with the same treatment of the second and third groups together for a period of 5 days a week. This continued until the end of chemotherapy (four doses of chemotherapy one of each dose through 21 days) and also after administering chemotherapy for two weeks.

The Edmonton Symptom Assessment System (ESAS) (Chang, et al., 2000) was used and this measuring scale aided in the assessment of nine symptoms common in cancer patients: pain, nausea, vomiting, diarrhea, appetite, fatigue, drowsiness, depression, and anxiety. This scale ranged from zero to 10 depending on the severity of symptoms of the patient and the recorded number corresponds to symptom of pain and the number zero means the absence of symptoms, while number 10 means feeling of severe symptoms. These figures were converted to degrees: zero there are no symptoms, $1-3$ mild symptoms, $4-7$ moderate symptoms, $8-10$ severe symptoms. This had been standard on the experimental groups before treatment, and every week during doses of chemotherapy (12 prescriptions, where a woman was given all 4 doses of chemotherapy, the chemotherapy dose for 21 days), and two weeks after the end of the last dose of chemotherapy. For the control group the measurement was applied for each dose per week during the chemotherapy, and two weeks after the end of the last dose of chemotherapy. The data were analyzed using the General Linear Model of the program (2000) SAS to estimate the mean, standard deviation and variance analysis and appreciation of the significant differences between the averages by Duncan test.

No symptoms

Severe symptoms

$\begin{array}{lllllllllll}0 & 1 & 2 & 3 & 4 & 5 & 6 & 7 & 8 & 9 & 10\end{array}$

\section{RESULTS AND DISCUSSION}

Table (1) indicated the degree of pain associated with the study sample, the results showed black seed or honey prior to treatment where the degree of pain did not exist in $22.22 \%$ of the study sample (54 women), while the degree of pain symptom to a moderate and severe degree at the rate of $35.19,42.59 \%$, respectively. Evidently, the low degree of pain during chemotherapy with black seed or honey treatment disappeared; whereas symptom of severe pain and mild pain by $100 \%$ in each group of black seed and honey. While in both groups of black seed and honey, the symptom of pain disappeared in $6.67 \%$ of the sample. The results of the statistical analysis showed lack of significant differences ( $p<0.20)$ between all groups. After two weeks of treatment, the pain disappeared in $38.89 \%$ of respondents, especially among the sample of honey and black seed, followed by other groups by $78.57,54.55 \%$, respectively. But after two weeks of resuming chemotherapy in the control group noted moderate and severe degree at the rate of $85.71,14.29 \%$, respectively. 
Table 1. The degree of pain symptom associated with breast cancers

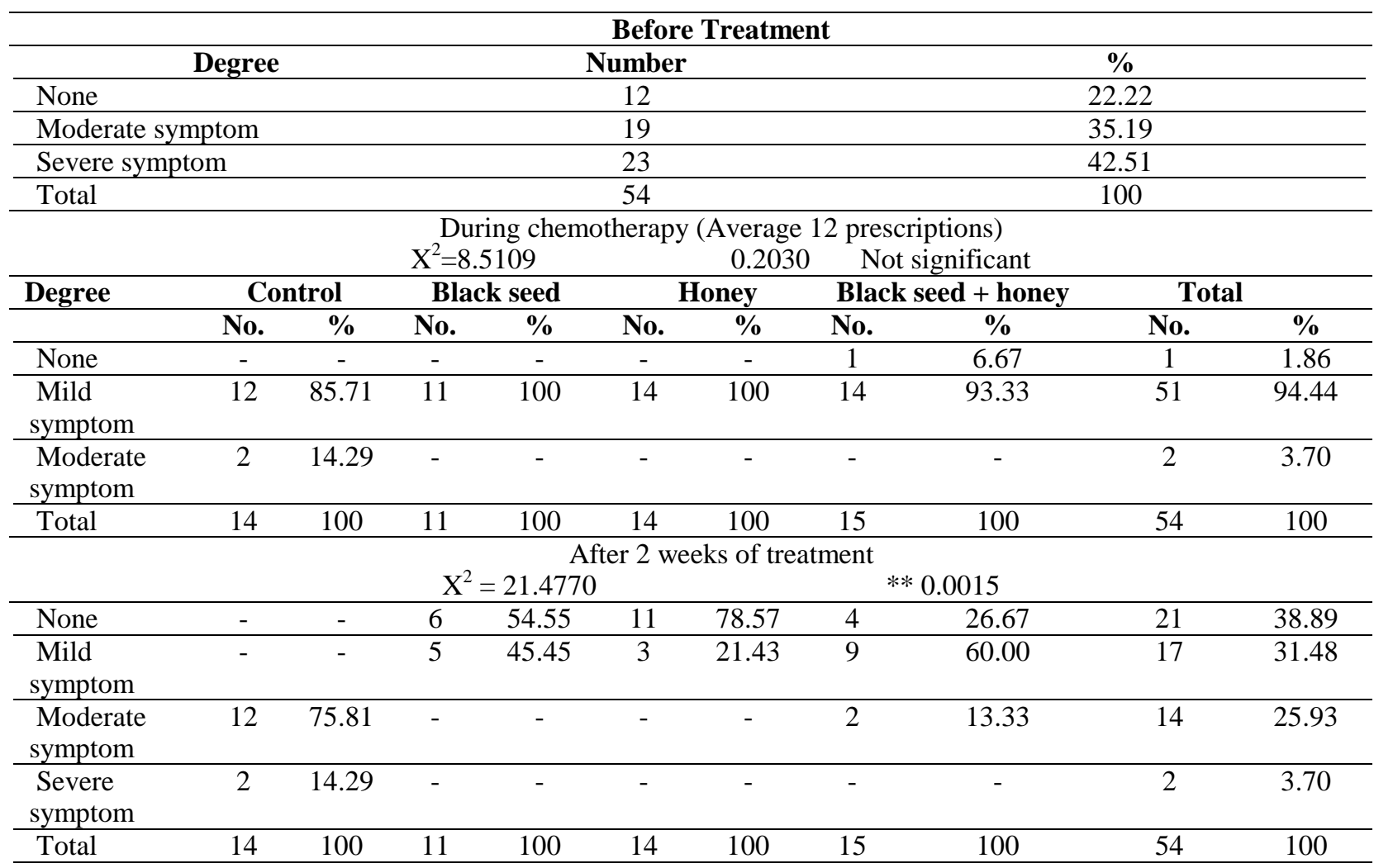

The results of statistical analysis chi square $\left(X^{2}\right)$ showed the existence of significant differences between all study samples at a level of probability of less than 0.0015 .

The results showed (Table 2) that the degree of symptom for nausea was severe, moderate, mild at the rate of $40.74,37.04,22.22 \%$ of the study sample, respectively. During chemotherapy and treatment of both black seed and honey nausea decreased by the rate of $9.26 \%$ of the sample, and mild symptom of nausea by the rate of $83.33 \%$ of the sample group, especially among black seed group, followed by honey. The differences were significant( $\mathrm{p}<0.0031)$ among the groups. After two weeks at the end of chemotherapy and treatment nausea disappeared by $51.85 \%$ among the total samples, and especially between groups of honey $(92.86 \%)$.While after two weeks the women sample in the control group suffered again from moderate and severe nausea. The results showed high significant differences ( $p<0.0002)$ between all groups.

The results(Table 3)showed the degree of symptom of vomiting with severe, moderate, and mild vomiting among the samples at the rate of $25.93,38.89$, and $27.78 \%$, respectively. While, the symptom of vomiting disappeared among the sample at the rate of $7.4 \%$ during chemotherapy, black seed or honey and in both black seed and honey. No symptom of vomiting up to $50 \%$ among the study sample, particularly between the two groups of honey and black seed and honey and black seed taken together. And the differences were statistically significant ( $\mathrm{P}<0.0001)$ among all groups. A continued improvement in the symptom of vomiting after two weeks by the end of chemotherapy and black seed or honey or in black seed and honey taken together. However, the percentage of $20.37,1.85 \%$ of the study sample had symptoms of moderate degree and severe vomiting. The results of statistical analysis indicated significant differences at the level of probability of less than 0.0006 .

The condition of diarrhea symptom improved for the study sample as a result of chemotherapy and black seed and honey; wherein the degree of symptoms of diarrhea was from moderate to mild by $35.18,37.04 \%$ before treatment. But after two weeks of treatment the symptoms of diarrhea disappeared by $72.22,70.37$, respectively. Statistical analysis did not show any significant differences between groups during treatment. It showed significant differences between groups when the probability level was 0.0087 (Table 4). 
Table 2. The degree of nausea symptom associated with the study sample

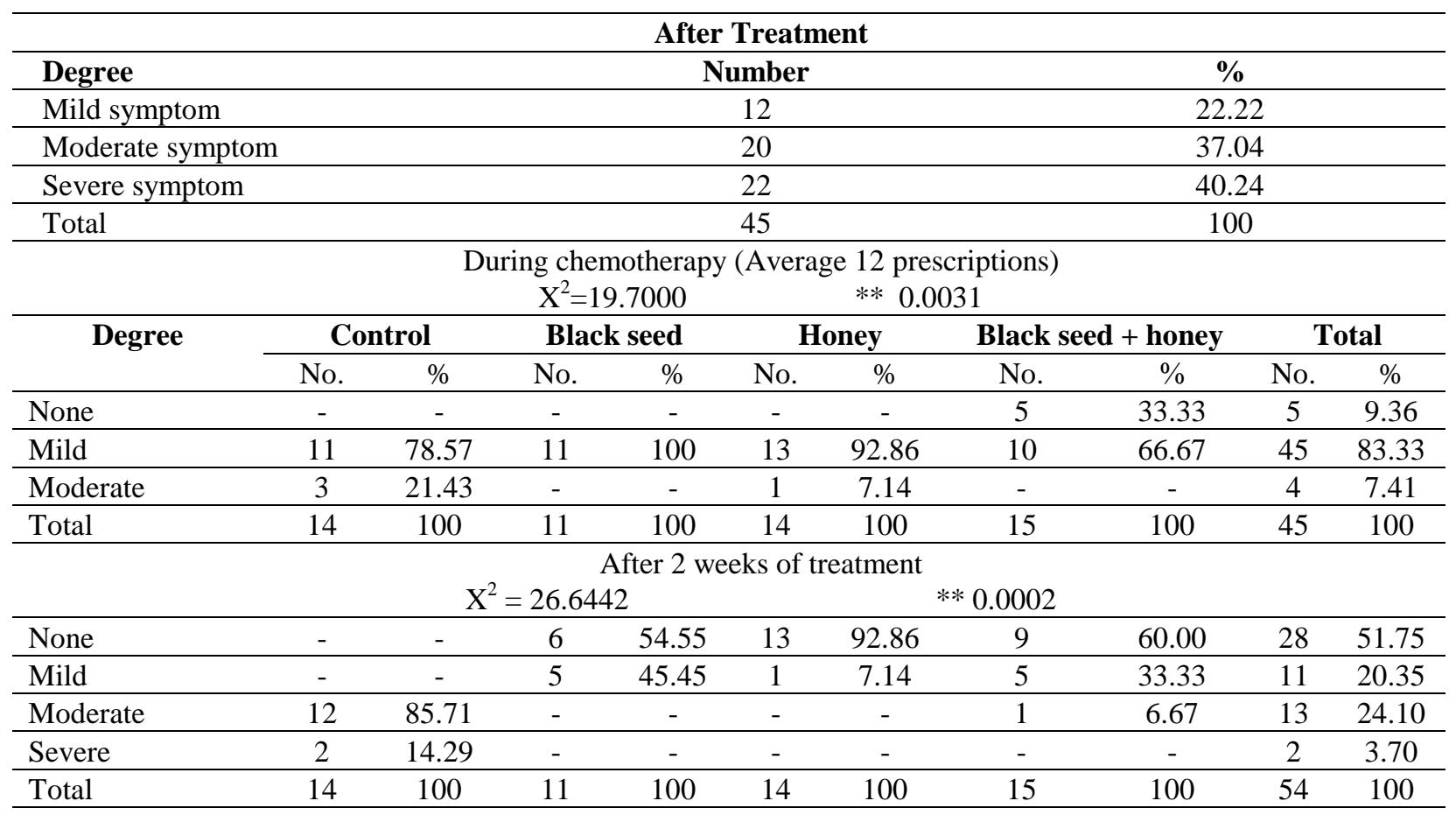

Table 3. The degree of vomiting symptom associated with the study sample

\begin{tabular}{lcc}
\hline & Before Treatment & \\
\hline Degree & Number & \% \\
\hline None & 4 & 7.40 \\
\hline Mild symptom & 15 & 27.78 \\
\hline Moderate symptom & 21 & 38.89 \\
\hline Severe symptom & 14 & 25.93 \\
\hline Total & 54 & 100 \\
\hline
\end{tabular}

During chemotherapy (Average 12 prescriptions)

$$
\mathrm{X}^{2}=30.4352 \quad * *=0.0001
$$

\begin{tabular}{|c|c|c|c|c|c|c|c|c|c|c|}
\hline \multirow[t]{2}{*}{ Degree } & \multicolumn{2}{|c|}{ Control } & \multicolumn{2}{|c|}{ Black seed } & \multicolumn{2}{|c|}{ Honey } & \multicolumn{2}{|c|}{ Black seed + honey } & \multicolumn{2}{|c|}{ Total } \\
\hline & No. & $\%$ & No. & $\%$ & No. & $\%$ & No. & $\%$ & No. & $\%$ \\
\hline None & 3 & 21.43 & - & - & 12 & 85.71 & 12 & 80.00 & 27 & 50.0 \\
\hline Mild symptom & 10 & 71.43 & 11 & 100 & 2 & 14.29 & 3 & 20.00 & 26 & 48.15 \\
\hline $\begin{array}{l}\text { Moderate } \\
\text { symptom }\end{array}$ & 1 & 7.14 & - & - & - & - & - & - & 1 & 1.85 \\
\hline Total & 14 & 100 & 11 & 100 & 14 & 100 & 15 & 100 & 54 & 100 \\
\hline \multicolumn{11}{|c|}{ After 2 weeks of treatment } \\
\hline \multicolumn{11}{|c|}{$\mathrm{X}^{2}=23.7846 \quad * * 0.0006$} \\
\hline None & 1 & 7.14 & 6 & 54.55 & 13 & 96.86 & 14 & 93.33 & 34 & 63.96 \\
\hline Mild symptom & 1 & 7.14 & 5 & 45.45 & 1 & 7.14 & 1 & 6.67 & 8 & 14.82 \\
\hline $\begin{array}{l}\text { Moderate } \\
\text { symptom }\end{array}$ & 11 & 78.58 & - & - & - & - & - & - & 11 & 20.37 \\
\hline Severe symptom & 1 & 7.14 & - & - & - & - & - & - & 1 & 1.85 \\
\hline Total & 14 & 100 & 11 & 100 & 14 & 100 & 15 & 100 & 54 & 100 \\
\hline
\end{tabular}


Table 4. The degree of diarrhea symptom associated with the study sample

\begin{tabular}{|c|c|c|}
\hline \multicolumn{3}{|c|}{ Before Treatment } \\
\hline Degree & Number & $\%$ \\
\hline None & 15 & 27.78 \\
\hline Mild symptom & 20 & 37.04 \\
\hline Moderate symptom & 19 & 35.18 \\
\hline Total & 54 & 100 \\
\hline
\end{tabular}

During chemotherapy (Average 12 prescriptions)

$\mathrm{X} 2=5.1702 \quad 0.1598$ Not significant

\begin{tabular}{|c|c|c|c|c|c|c|c|c|c|c|}
\hline \multirow[t]{2}{*}{ Degree } & \multicolumn{2}{|c|}{ Control } & \multicolumn{2}{|c|}{ Black seed } & \multicolumn{2}{|c|}{ Honey } & \multicolumn{2}{|c|}{$\begin{array}{c}\text { Black seed + } \\
\text { honey }\end{array}$} & \multicolumn{2}{|c|}{ Total } \\
\hline & No. & $\%$ & No & $\%$ & No. & $\%$ & No. & $\%$ & No. & $\%$ \\
\hline None & 7 & 50.00 & 8 & 72.73 & 12 & 85.71 & 12 & 80.00 & 39 & 72.22 \\
\hline Mild symptom & 7 & 50.00 & 3 & 77.27 & 2 & 14.29 & 3 & 20.00 & 15 & 27.78 \\
\hline Total & 14 & 100 & 11 & 100 & 14 & 100 & 15 & 100 & 54 & 100 \\
\hline \multicolumn{11}{|c|}{ After 2 weeks of treatment } \\
\hline & \multicolumn{4}{|c|}{$X^{2}=21.4770$} & \multicolumn{3}{|c|}{$* 0.0015$} & & & \\
\hline None & 4 & 7 & 10 & 90.09 & 12 & 85.71 & 12 & 80.00 & 38 & 70.37 \\
\hline Mild symptom & - & - & 1 & 9.09 & 2 & 14.29 & 3 & 20.00 & 6 & 11.11 \\
\hline Moderate symptom & 4 & 28.57 & - & - & - & - & - & - & 4 & 7.41 \\
\hline Severe symptom & 6 & 42.86 & - & - & - & - & - & - & 6 & 11.11 \\
\hline Total & 14 & 100 & 11 & 100 & 14 & 100 & 15 & 100 & 54 & 100 \\
\hline
\end{tabular}

When studying the degree of the symptom in loss of appetite among the study sample (Table 5) it turned out to be that symptoms of severe and moderate loss of appetite was severe among women prior to treatment and was increased by $44.45,35.18 \%$, respectively. While after treatment a decreased symptom of loss of appetite and a symptom of mild anorexia is at the rate of $88.89 \%$ among all study sample, but the differences were not significant. After two weeks by the end of treatment loss of appetite disappeared among all infected study sample at the rate of $38.89 \%$, especially among the group of honey followed by group of black seed while loss of appetite increased to moderate by $85.71 \%$ in sample of control group. The significant difference between groups was $(\mathrm{p}<0.0010)$.

Table (6) indicated the degree of fatigue that accompanies the study sample, where half of the sample had moderate symptom of fatigue, and the other half had symptoms of mild and severe fatigue, before treatment. During chemotherapy most of the respondents $(83.33 \%)$ had mild symptom of fatigue and there were no significant differences between groups. After two weeks of chemotherapy and black seed or honey treatment, or black seed and honey taken together, fatigue disappeared in nearly half of the sample $(46.30 \%)$. But then again the feeling of fatigue was moderate in the sample of the control group $(85.72 \%)$ The results of statistical analysis indicated significant differences at the level of significance less than 0.0020 .

Table (7) indicated the degree of feeling drowsy before chemotherapy with the treatment of either black seed or honey; where in percentages of $27.77,51.86$, $20.37 \%$ of the sample had symptoms of mild, moderate, and severe drowsiness, respectively. And during the sessions of chemotherapy and treatment of both black seed and honey the feeling of drowsiness were mild or completely disappeared at $79.63,20.37 \%$, respectively. There were no significant differences between groups. After two weeks by the end of therapeutic sessions for all samples the feeling of drowsiness was mild or completely disappeared at $20.37,57.41 \%$, respectively.

The degree of symptoms of depression in the study sample was severe, moderate and mild by rate of 18.52 , $59.26,22.22 \%$, respectively. But the symptom of depression disappeared during the treatment of chemotherapy in study samples who took black seed or honey, or both. The differences were significant. And also symptom of depression disappeared after two weeks of chemotherapy and the highest percentage for the sample of the study who took black seed and then honey and finally the group that took black seed and honey together. The differences were significant at the level of probability of less than 0.0001 (Table 8 ). 
Table 5. The degree of appetite loss that accompanies the study sample

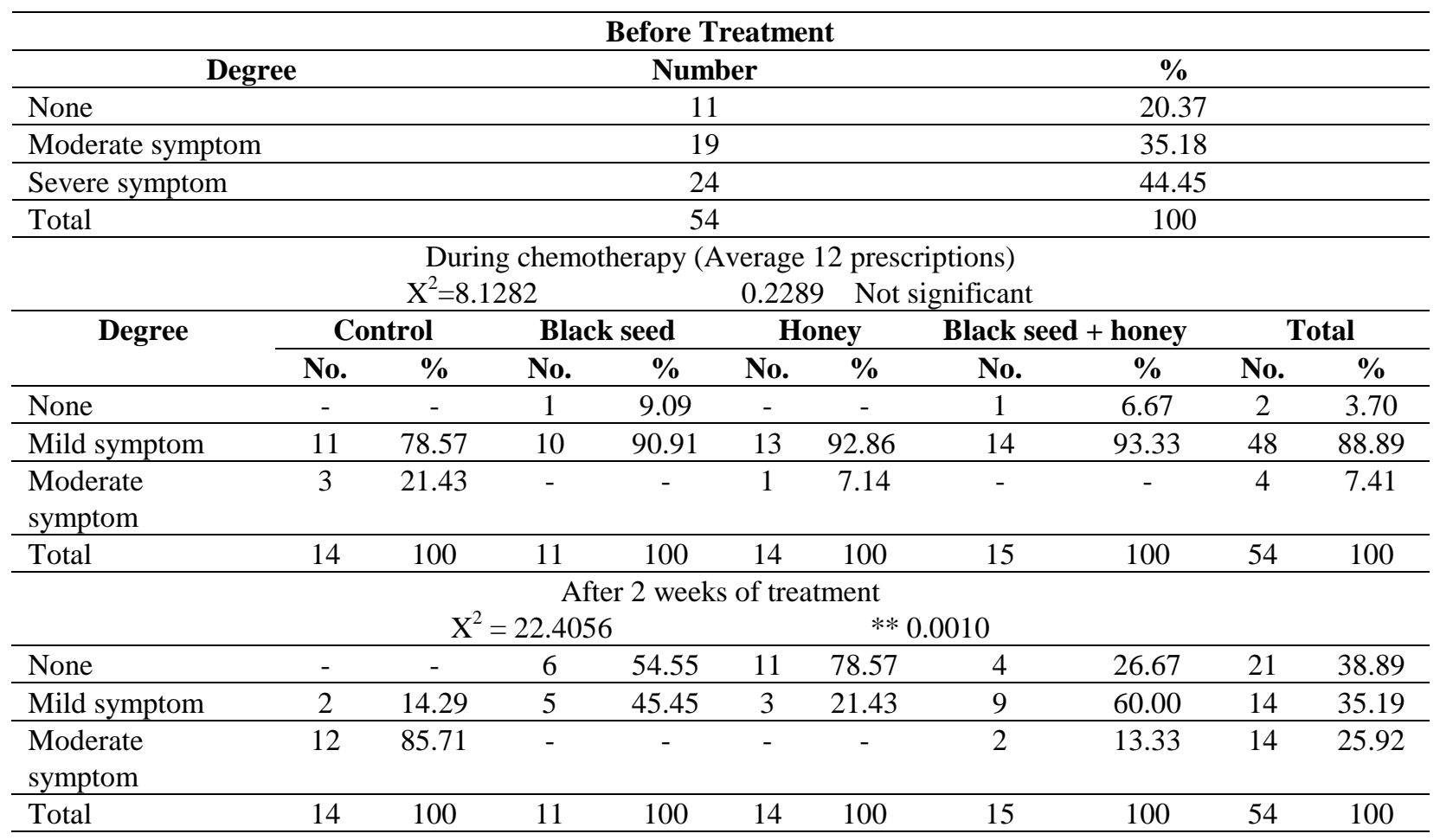

Table 6. The degree of fatigue symptom associated with the study sample

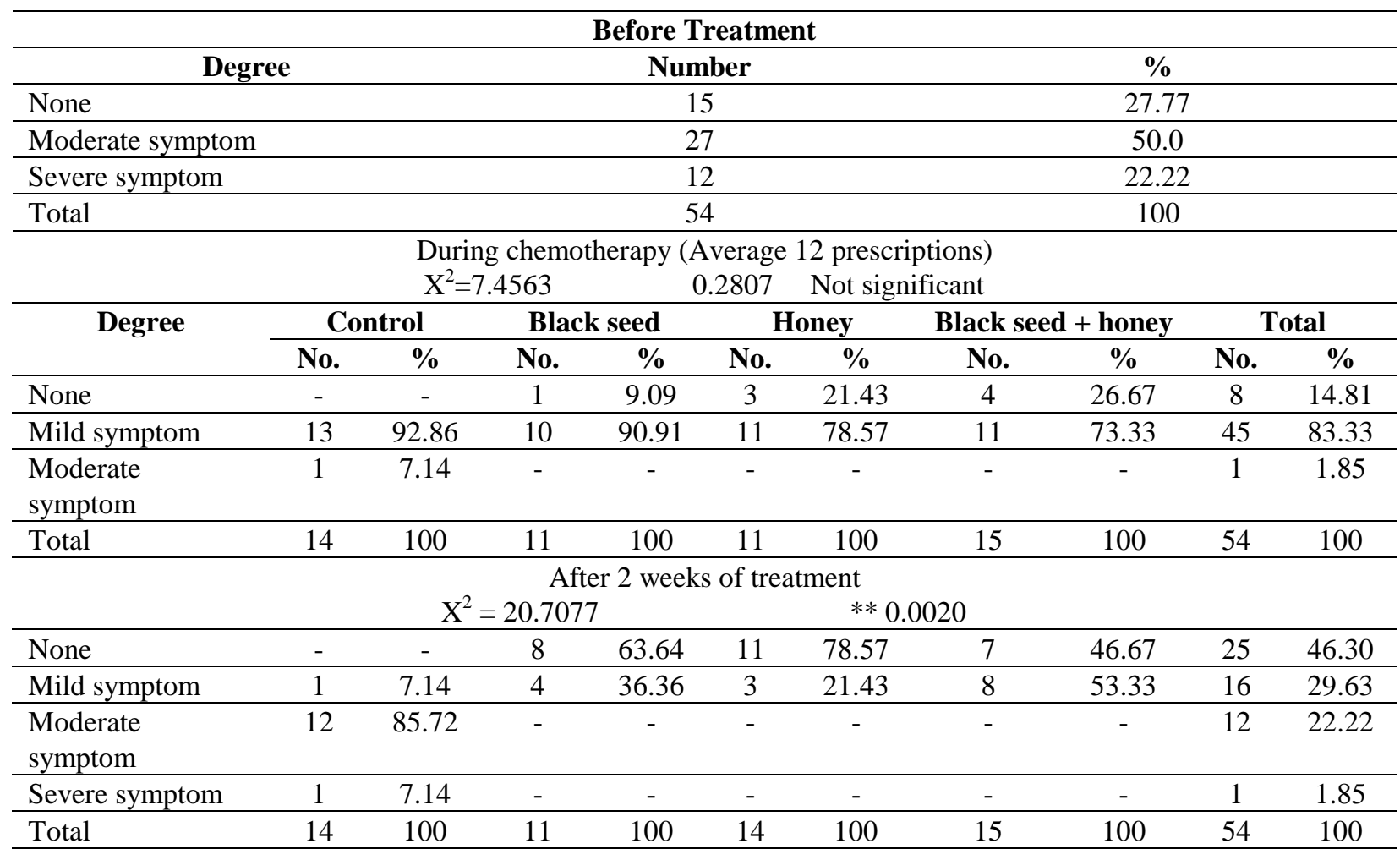


Table 7. The degree of drowsiness symptom associated with the study sample

\begin{tabular}{|c|c|c|c|c|c|c|c|c|c|c|}
\hline \multicolumn{11}{|c|}{ Before Treatment } \\
\hline Degree & & & \multicolumn{4}{|c|}{ Number } & \multicolumn{4}{|c|}{$\%$} \\
\hline None & & & \multicolumn{4}{|c|}{15} & \multicolumn{4}{|c|}{27.77} \\
\hline Moderate symptom & & & \multicolumn{4}{|c|}{28} & \multicolumn{4}{|c|}{51.86} \\
\hline Severe symptom & & & \multicolumn{4}{|c|}{11} & \multicolumn{4}{|c|}{20.37} \\
\hline Total & & & \multicolumn{4}{|c|}{54} & \multicolumn{4}{|c|}{100} \\
\hline \multicolumn{11}{|c|}{ During chemotherapy (Average 12 prescriptions) } \\
\hline & & $=6.0125$ & & 0.111 & & t signifi & & & & \\
\hline \multirow[t]{2}{*}{ Degree } & \multicolumn{2}{|c|}{ Control } & \multicolumn{2}{|c|}{ Black seed } & \multicolumn{2}{|c|}{ Honey } & \multicolumn{2}{|c|}{ Black seed + honey } & \multicolumn{2}{|c|}{ Total } \\
\hline & No. & $\%$ & No. & $\%$ & No. & $\%$ & No. & $\%$ & No. & $\%$ \\
\hline None & - & - & 2 & 18.18 & 5 & 35.71 & 4 & 26.67 & 11 & 20.37 \\
\hline Mild symptom & 14 & 100 & 9 & 81.82 & 9 & 64.29 & 11 & 73.33 & 43 & 79.63 \\
\hline Total & 14 & 100 & 11 & 100 & 14 & 100 & 15 & 100 & 54 & 100 \\
\hline \multicolumn{11}{|c|}{ After 2 weeks of treatment } \\
\hline & \multicolumn{3}{|c|}{$X^{2}=26.693$} & \multicolumn{3}{|c|}{$* * 0.000$} & & & & \\
\hline None & - & - & 8 & 72.73 & 12 & 85.71 & 11 & 73.33 & 31 & 53.41 \\
\hline Mild symptom & 2 & 14.29 & 3 & 27.27 & 2 & 14.29 & 4 & 26.67 & 11 & 20.37 \\
\hline Moderate symptom & 12 & 85.71 & - & - & - & - & - & - & 12 & 22.22 \\
\hline Total & 14 & 100 & 11 & 100 & 14 & 100 & 15 & 100 & 54 & 100 \\
\hline
\end{tabular}

Table 8. The degree of depression symptom associated with the study sample

\begin{tabular}{lcc}
\hline \multicolumn{1}{c}{ Degree } & Before Treatment & \\
\hline None & Number & \% \\
\hline Moderate symptom & 12 & 22.22 \\
\hline Severe symptom & 32 & 59.26 \\
\hline Total & 10 & 18.52 \\
\hline
\end{tabular}

During chemotherapy (Average 12 prescriptions)

$$
\mathrm{X}^{2}=14.4987
$$

$$
* 0.0245
$$

\begin{tabular}{|c|c|c|c|c|c|c|c|c|c|c|}
\hline \multirow[t]{2}{*}{ Degree } & \multicolumn{2}{|c|}{ Control } & \multicolumn{2}{|c|}{ Black seed } & \multicolumn{2}{|c|}{ Honey } & \multicolumn{2}{|c|}{ Black seed + honey } & \multicolumn{2}{|c|}{ Total } \\
\hline & No. & $\%$ & No. & $\%$ & No. & $\%$ & No. & $\%$ & No. & $\%$ \\
\hline None & - & - & 5 & 45.45 & 8 & 57.14 & 8 & 53.33 & 21 & 38.88 \\
\hline Mild symptom & 12 & 85.71 & 6 & 45.55 & 5 & 35.71 & 7 & 46.67 & 30 & 55.56 \\
\hline Moderate symptom & 2 & 14.29 & - & - & 1 & 7.14 & - & - & 3 & 5.56 \\
\hline Total & 14 & 100 & 11 & 100 & 14 & 100 & 15 & 100 & 54 & 100 \\
\hline \multicolumn{11}{|c|}{ After 2 weeks of treatment } \\
\hline \multicolumn{11}{|c|}{$\mathrm{X}^{2}=8.2938 \quad * *$} \\
\hline None & - & - & 10 & 90.91 & 11 & 78.57 & 9 & 60.00 & 30 & 55.55 \\
\hline Mild symptom & - & - & 1 & 9.09 & 3 & 21.43 & 6 & 40.00 & 10 & 18.52 \\
\hline $\begin{array}{l}\text { Moderate } \\
\text { symptom }\end{array}$ & 14 & 100 & - & - & - & - & - & - & 14 & 25.93 \\
\hline Total & 14 & 100 & 11 & 100 & 14 & 100 & 15 & 100 & 54 & 100 \\
\hline
\end{tabular}


The results of the study (Table 9) showed that the degree of anxiety before therapy sessions in study samples were severe, moderate, mild at the rate of $38.88,35.19,25.93 \%$, respectively. Similarly, there was no symptom of anxiety among the sample during the course of treatment and also two weeks after treatment with a rate of $18.52 \%$, especially between groups of black seed or honey or both. After two weeks of treatment, anxiety had increased in samples of the control group, either moderate or severe in degree. However, statistical analysis did not show significant differences between groups.

The Fernsler (2003) stated that there must be an accurate assessment of health status and psychological evaluation of patients before starting chemotherapy. The information will help the medical team in charge of identifying risk factors that could contribute to the occurrence of side effects or increase its severity. In addition another factor that may affect the response of breast cancer patients to treatment is the age and general condition, chronic diseases and nutritional status.
Garofolo, et al. (2005) indicated that the treatment of cancer, particularly chemotherapy and radiation, are important factors affecting nutrition. The treatment is associated with many side effects such as nausea, vomiting, inflammation of mucous membranes, constipation, and anorexia, which plays a role in loss of appetite, loss of nutrients, changes in energy discharge, weight loss, especially from modifying fatty tissues of the body and these conditions leads to malnutrition, especially when chemotherapy sessions is repeated at frequent intervals.

Cancer Compass (2008) also recollected the side effects of biological treatment of cancer patients that often appeared during the first dose of treatment of Herceptin and include fever, chills, pain, emaciation, nausea, vomiting, diarrhea, headache, breathing difficulty, itching skin; treatment also causes damage to the heart and lead to heart failure, and may affect the lungs and cause breathing problems. Al-thabit (2009) noted that women with breast cancer suffer from a psychological challenges and pressures, such as concerns about their health and future and how to cope with the disease.

Table 9. The degree of anxiety symptom associated with breast cancers

\begin{tabular}{|c|c|c|c|c|c|c|c|c|c|c|}
\hline \multicolumn{11}{|c|}{ Before Treatment } \\
\hline \multicolumn{3}{|c|}{ Degree } & \multicolumn{4}{|c|}{ Number } & \multicolumn{4}{|c|}{$\%$} \\
\hline None & & & \multicolumn{4}{|c|}{14} & \multicolumn{4}{|c|}{25.93} \\
\hline Moderate symptom & & & \multicolumn{4}{|c|}{19} & \multicolumn{4}{|c|}{35.19} \\
\hline Severe symptom & & & \multicolumn{4}{|c|}{21} & \multicolumn{4}{|c|}{38.88} \\
\hline Total & & & \multicolumn{4}{|c|}{54} & \multicolumn{4}{|c|}{100} \\
\hline \multicolumn{11}{|c|}{ During chemotherapy (Average 12 prescriptions) } \\
\hline \multicolumn{11}{|c|}{$X^{2}=6.5504 \quad 0.3644$ Not significant } \\
\hline \multirow[t]{2}{*}{ Degree } & \multicolumn{2}{|c|}{ Control } & \multicolumn{2}{|c|}{ Black seed } & \multicolumn{2}{|c|}{ Honey } & \multicolumn{2}{|c|}{ Black seed + honey } & \multicolumn{2}{|c|}{ Total } \\
\hline & No. & $\%$ & No. & $\%$ & No. & $\%$ & No. & $\%$ & No. & $\%$ \\
\hline None & - & - & 2 & 18.18 & 4 & 28.57 & 4 & 26.67 & 10 & 18.52 \\
\hline Mild symptom & 3 & 92.86 & 9 & 81.82 & 9 & 64.29 & 11 & 73.33 & 42 & 77.78 \\
\hline Moderate symptom & 1 & 7.14 & - & - & 1 & 7.14 & - & - & 2 & 3.70 \\
\hline Total & 14 & 100 & 11 & 100 & 14 & 100 & 15 & 100 & 54 & 100 \\
\hline \\
\hline \multicolumn{11}{|c|}{$\begin{array}{l}\text { After } 2 \text { weeks of treatment } \\
\qquad \text { Not significant } 0.3644\end{array}$} \\
\hline None & - & - & 2 & 18.18 & 4 & 28.57 & 4 & 26.67 & 10 & 18.52 \\
\hline Mild symptom & 1 & 7.14 & 9 & 81.82 & 9 & 64.29 & 11 & 73.33 & 30 & 55.55 \\
\hline Moderate symptom & 10 & 71.43 & - & - & 1 & 7.17 & - & - & 11 & 20.37 \\
\hline Severe symptom & 3 & 21.43 & - & - & - & - & - & - & 3 & 5.56 \\
\hline Total & 14 & 100 & 11 & 100 & 14 & 100 & 15 & 100 & 54 & 100 \\
\hline
\end{tabular}


The scale was designed to measure psychological pressure and psychological, social and marital adjustment for 198 married Jordanian patients with early breast cancer, ages between (20-70) years and came back to Hussein Cancer Center for follow-up treatment and examination after surgery. The study recommended the need for psychological, social, marital support, and educate women with breast cancer and their families about coping strategies for adjusting to stress, especially for those young women and women with low educational level, as well as the need to identify sources of stress, according to personal and clinical characteristics of the patient such as age, educational level, social, duration of treatment, and stage of the disease.

It is concluded from this study the importance of the use of complementary and alternative treatment by using natural foods especially black seed and honey for the prevention and protection from cancer or alleviation of symptoms associated with different treatments of cancer. In addition natural foods treatment reduces or avoids side effects of chemical treatment. Wherein the components of black seed and honey interfere with various stages as to the process of cancer formation by affecting the interaction pathways within cells and which may represent a molecular mechanism for the prevention of cancer. And honey distinct characteristics are antiinflammatory, antioxidant, anti-tumor growth, stimulating apoptosis, and its impact on the immune system where honey contains approximately 181 active ingredients. As to the black seed their impact is due to its ability to destroy cancer cells, and increase the number of cells producing antibodies and effectiveness of anti-tumor growth.

\section{REFERENCES}

Alharbi, A. (2008): The effect of chemotherapy on nutritional status of breast cancer patients. Master's degree in the department of community health sciences at the college of applied medical sciences King Saud University. American Cancer Society.

Al-thabit, A. (2009): Psychological stresses and its relation to psychological, social, marital adjustment in women with early breast cancer in Jordan. PhD. Oman. Jordan.
Cancer Compass/ Breast Cancer Information/ Side Effects (2008). www. Cancer Compass.com.

Chang, V.; Hwang, S. and Feuerrman, M.(2000): Validation of the Edmonton Symptom Assessment Scale. Cancer.1; 88 (9): 216471.

Debasis, B. and Preuss, H.(2005): Phytopharmaceuticals in Cancer Chemoprevention. CRC Press. Boca Raton London New York Washington, D.C.

Edris, A. (2009): Anti-Cancer Properties of Nigella spp. Essential Oils and their Major Constituents, Thymoquinone and $\beta$-Elemene. Current Clinical Pharmacology. 4(43):46 - 43.

Fernsler, J.(2003): Psychological Impactions of adjuvant chemotherapy: A two- years follow -up. Cancer Nursing. 52:154-60.

Garofolo, A.; Lopez, F. and Petrilli, A. (2005): High prevalence of malnutrition among patients with solid nonhematological tumors as found by using skin fold and circumference measurements. Sao Paulo Med J.123:277281.

Ibrahim, E.; Zeeneldin, A. and Bin Sadiq, B. (2008):The present and the future of breast cancer burden in the Kingdom of Saudi Arabia. Journal of Clinical Oncology, 2008 ASCO Annual Meeting Proceedings. 26: 15S.

Ministry of Health (2007): Health Statistical Year Book. Kingdom of Saudi Arabia.

Mohamad, R. ; Al-Said, M. Zekry, Z.; Hamza, M. ; ElHaddad, M. El-Shaieb, S. ; Al-Mehdar, H. ; Sharawy, S. and El- Marzbani, M. (2011): Evaluation of immune status in patients with breast cancer who received some natural supplements as a as Adjuvant therapy after the completion of receipt of the anti-cancer treatments. Tenth International Conference of the scientific miracles in the Quran and the Sunnah. Istanbul, Turkey. $11-14$ March 2011.

Mufti, M. (2007): Tumors and breast surgery: House for publication and public distribution and advertising, the National Library, the first edition, Benghazi. Libya.

SAS "Statistical Analysis System" (2000): SAS user guide: Statistics Version 8 edition, Inc., Carry, NC.

World Health Organization news release. (WHO):2003.http://www. who.int/ mediacentre/ news/ release s/2003/pr27/en/. 


\section{الملخص العربي}

\section{دور الحبة السوداء وعسل النحل في تخفيف درجة الإحساس بالأعراض المصاحبة للمصابات}

\section{بسرطان الثدي}

$$
\text { سوزان عبد الرحمن صالح أبو شال }
$$

بجموعتي عسل النحل والحبة السوداء وعسل النحل معا.اختفى

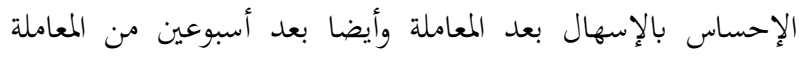
خاصة بين مجموعة العسل، وبموعة الحبة السوداء وعسل النحل معا.

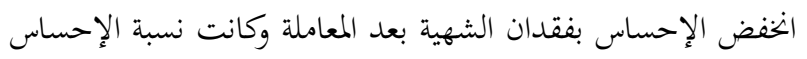

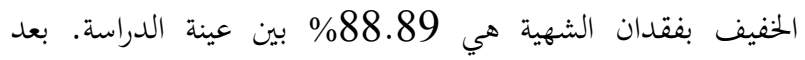

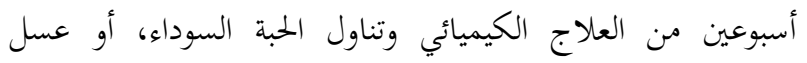

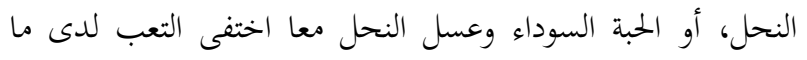
يقارب نصف العينة(46.30\%). أثناء دورات العلاج الكيميائي

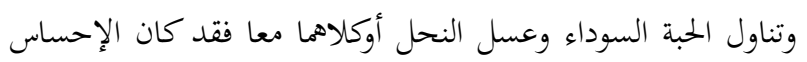
بالنعاس خفيفاً, أواختفى تماما لدى وعسل النحل اوداء

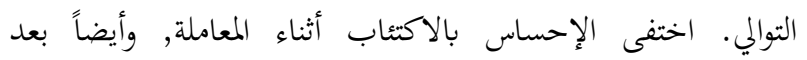
أسبوعين من المعاملة في المجموعات التجريبية الثلاثة. تشابه عدم وجود الاحسياء اي قلق بين العينات أثناء دورات العلاج, وأيضاً بعد العلاج بأسبوعين وذلك بنسبة 18.52\%،وخاصة بين مجموعات الحبة

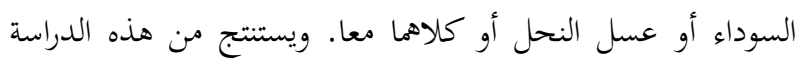

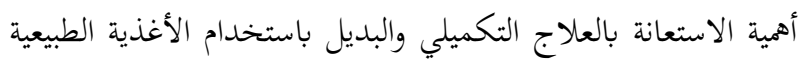

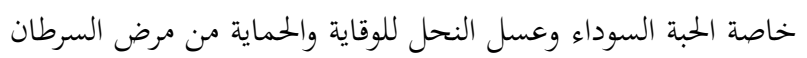

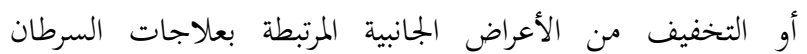

المختلفة.
استهدفت هذه الدراسة التعرف على تأثير تناول كل من الحبة

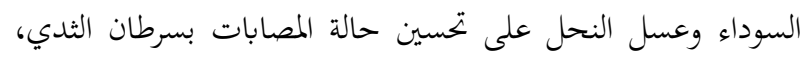
أجريت الدراسة في قسم الأورام بمستشفى النور التخصصي ومدينة

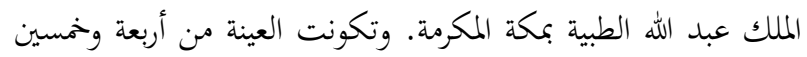
مريضة وقد تراوحت أعمارهن من أكثر من 18 سنة إلى 70 سنة.

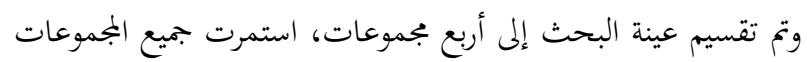
14)

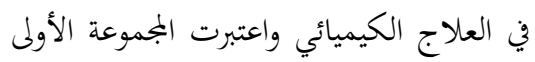
مريضة) ججموعة ضابطة، والمجموعة الثانية(11مريضة) تناولت

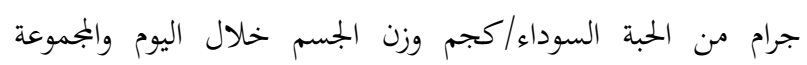
الثالثة(14 مريضة) تناولت 60 جرام من العسل خلام التهوداء اليوم. بينما

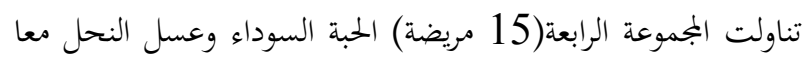
بنفس جرعات المجموعة الثانية والثالثة معا وذلك لمدة 5 أيام في إنيه

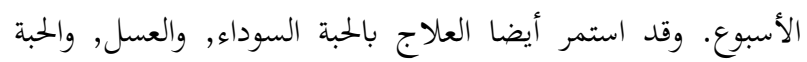
السوداء والعسل معاً لمدة أسبوعين بعد انتهاء العلاج الكيميائي. وفئ. أشارت النتائج لحدوث الخغاض في درجة الإحساس بالألم أثناء

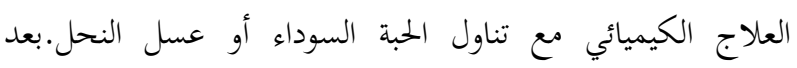
أسبوعين من فاية العلاج الكيميائي والغذائي فقد اختفي الإحساس الغاء بالغثيان بين 851.85\% من مجموع العينات. أثناء العلاج الكيميائي ارتفعت نسبة عدم الإحساس بالقيء إلى50\% بين العينة وخاصة بين 